\begin{tabular}{|l|l|l|}
\hline \multicolumn{2}{|c|}{ PublisherInfo } \\
\hline \hline PublisherName & $:$ & BioMed Central \\
\hline \hline PublisherLocation & $:$ & London \\
\hline \hline PublisherImprintName & $:$ & BioMed Central \\
\hline \hline
\end{tabular}

\title{
Levels of synteny between rice and maize
}

\begin{tabular}{|l|l|l||}
\hline \multicolumn{2}{|c|}{ ArticleInfo } \\
\hline \hline ArticleID & $:$ & 3624 \\
\hline \hline ArticleDOI & $:$ & $10.1186 /$ gb-2000-1-2-reports0047 \\
\hline \hline ArticleCitationID & $:$ & reports0047 \\
\hline \hline ArticleSequenceNumber & $:$ & 21 \\
\hline \hline ArticleCategory & $:$ & Paper report \\
\hline ArticleFirstPage & $:$ & 1 \\
\hline \hline ArticleLastPage & $:$ & 3 \\
\hline \hline & & RegistrationDate : 2000-4-30 \\
ArticleHistory & $:$ & Received \\
\hline ArticleCopyright & $:$ & BioMed Central Ltd2000-4-30 \\
\hline \hline ArticleGrants & $:$ & \\
\hline \hline
\end{tabular}




\begin{tabular}{|l|l|l||}
\hline ArticleContext & $:$ & 130591122 \\
\hline
\end{tabular}

\section{Todd Richmond}

\section{Abstract}

A portion of the rice genome has been examined in order to evaluate the feasibility of using rice as a surrogate genome for map-based cloning of maize genes.

\section{Significance and context}

A number of studies over the past few years have examined the similarities between the various plant genomes. As the rice genome sequence is nearing completion, researchers are anxious to know if sequence information from rice can be used to facilitate map-based cloning in other closely related grass species, such as maize and sorghum. Tarchini et al. have discovered that the presence of rapidly evolving gene families and microtranslocations in the rice genome may hamper its use as a model system for cloning genes in other organisms.

\section{Key results}

Tarchini et al. completely sequenced a $340 \mathrm{~kb}$ region surrounding the rice $A d h 1$ and $A d h 2$ loci as the starting point for their analysis of colinearity between rice and maize. The $A d h 1$ region is a logical starting point because it has been the subject of detailed analysis in other crop species. The authors discovered 33 putative genes in the region, including Adh1 and Adh2. Twelve of the genes show similarity to genes of known function, most related to disease resistance. Frequent gene duplications were seen, closely spaced and mostly in the same orientation. Similar duplications have been found in Arabidopsis and suggest that gene duplication events are a common occurrence in plant genome evolution. Almost $30 \%$ of the region comprises repetitive elements, including retrotransposons, transposons, miniature inverted-repeat transposable elements, and simple-sequence repeats. Thirteen of the loci in the region were tested for their ability to cross-hybridize with maize genomic DNA. Only five genes hybridized well, and only three of those showed useful polymorphisms in the maize mapping populations tested. The authors' results indicate microcolinearity between the $A d h 1-A d h 2$ region on rice chromosome 11 and the $A d h 2$ region on maize chromosome 4. Data from other labs have shown that the maize Adhl gene is on maize chromosome 1, indicating that at some point after the duplication event that created $A d h 1$ and $A d h 2$, a translocation occurred in maize (and sorghum), placing the two Adh genes in these species on different chromosomes. The limited success of Tarchini et al. with crosshybridization of rice genes with maize genomic DNA, as well as gene duplications, divergent selection 
and micro- and macro-translocation events in the grasses generally, suggest that there will be complications in using rice to facilitate map-based cloning in maize. There appear to be blocks of microcolinearity, interspersed with unrelated genes and repetitive elements. These results agree with those of others, and suggest that this approach will have to be evaluated on a case-by-case basis.

\section{Reporter's comments}

Tarchini et al. make no comparison between their sequence and the published sequence for the Adh1 regions from maize $(225 \mathrm{~kb})$ and sorghum $(75 \mathrm{~kb})$. This may be because most of the relevant sequence does not overlap, as a result of the translocation that separated $A d h 1$ and $A d h 2$ in sorghum and rice. Because of this translocation, the most useful sequence for comparison from maize is from the $A d h 2$ gene found on maize chromosome 4 (which has not been sequenced). The authors have anchored their sequence region on one end with the $A d h 1-A h d 2$ region, rather than centering the $340 \mathrm{~kb}$ region around those two genes. In the latter arrangement, more useful sequence comparisons could have been made between rice and the previously published sorghum and maize sequences. Unfortunately, because of this, most of the paper seems concerned with describing the putative genes and repetitive elements in the region. Perhaps a more useful approach would have been to take a number of the completely sequenced regions from the Rice Genome Project, and use molecular markers to isolate maize bacterial artificial chromosome (BAC) clones for sequencing. Then direct sequence comparisons could be made both at the single-gene level and at the level of genome organization.

\section{Table of links}

Plant Cell

\section{References}

1. Tarchini R, Biddle P, Wineland R, Tingey S, Rafalski A: The complete sequence of $340 \mathrm{~kb}$ of DNA around the rice $A d h 1-A d h 2$ region reveals interrupted colinearity with maize chromosome 4. Plant Cell. 2000, 12: 381-391. 1040-4651

This PDF file was created after publication. 